University at Buffalo School of Law

Digital Commons @ University at Buffalo School of Law

\title{
Why Federalism and Constitutional Positivism Don't Mix
}

James A. Gardner

University at Buffalo School of Law, jgard@buffalo.edu

Follow this and additional works at: https://digitalcommons.law.buffalo.edu/book_sections

Part of the Constitutional Law Commons

\section{Recommended Citation}

James A. Gardner, Why Federalism and Constitutional Positivism Don't Mix in New Frontiers of State Constitutional Law: Dual Enforcement of Norms (James A. Gardner \& Jim Rossi, eds., Oxford University Press 2010)

New Frontiers of State Constitutional Law: Dual Enforcement of Norms edited by James A. Gardner, and Jim Rossi, 2010, reproduced by permission of Oxford University Press, 10.1093/acprof:oso/9780195368321.003.0004.

\section{C. ${ }_{\text {COPYRIGHT }}^{\text {IN }}$}

This Book is brought to you for free and open access by the Faculty Scholarship at Digital Commons @ University at Buffalo School of Law. It has been accepted for inclusion in Contributions to Books by an authorized administrator of Digital Commons @ University at Buffalo School of Law. For more information, please contact lawscholar@buffalo.edu. 


\title{
Chapter 4
}

\section{Why Federalism And Constitutional Positivism Don't Mix}

\author{
James A. Gardner
}

\section{Introduction}

Ever since state constitutional law arrived as a field of study twenty years ago, its most pressing and contentious problem has concerned the question of how state constitutions ought to be interpreted, and in particular whether the appropriate methods for interpreting a state constitution differ from those commonly employed in analyzing the federal Constitution. ${ }^{1}$ In the course of this ongoing debate, it has frequently been argued that state constitutions ought to be interpreted using a methodology of strict constitutional positivism. I shall define "constitutional positivism" more formally below. For now, it is sufficient to say that constitutional positivism is, broadly speaking, a familiar and commonplace theory of interpretational legitimacy that requires courts to approach a constitution as an authoritative expression of the will of the people who made it, and to interpret the constitution strictly in accordance with that popular will as it is expressed in the document. I shall argue in this Chapter that the interpretational methodology of constitutional positivism, which furnishes the dominant approach to the interpretation of the U.S. Constitution, cannot simply be lifted from federal constitutional law and applied willy-nilly to state constitutions. Although it is possible, and perhaps desirable, to adapt the methods of constitutional positivism to the interpretation of state constitutions, substantial modifications must be made before such methods can be used successfully in this very different setting.

In their strongest statements, advocates of a state constitutional jurisprudence of constitutional positivism sometimes argue that only the narrowest positivist approaches to constitutional interpretation, such as textualism ${ }^{2}$ or originalism, ${ }^{3}$ should be applied to state constitutions. But even in its most general and moderate formulations, advocates of strict positivist approaches are united by a methodological belief that the job of the interpreter is, essentially, to pay really close and exclusive attention to the state constitution and its unique and exclusive interpretational props -- its text, the intentions of its framers, its relevant history, and so on. Certainly, an interpreter proceeding in the strict positivist mode would have no business relying on the text, framers' intentions, or founding history of any other constitution; the central tenet of constitutional positivism is that the only constitution that is relevant for purposes of

\footnotetext{
${ }^{1}$ For an overview, see G. AlAn TARR, Understanding State Constitutions, ch. 6 (1998).

${ }^{2}$ Textualism holds that, in most cases and for most purposes, the meaning of a constitutional provision can and should be discerned by examining the text alone. See, e.g., Paul Brest, The Misconceived Quest for the Original Understanding, 60 B.U. L. REV. 204, 205-17 (1980) (examining the method and rationale of textualism).

${ }^{3}$ Originalism holds that the meaning of a constitutional provision can and should be adduced by examining the intentions of the provision's framers and ratifiers. For a good overview of originalism, see Daniel Farber, The Originalism Debate: A Guide for the Perplexed, 49 OHIO ST. L. J. 1085 (1989). On the link between originalism and constitutional positivism, see James A. Gardner, The Positivist Foundations of Originalism: An Account and Critique, 71 B.U. L. REV. 1, 6-9 (1991).
} 
interpretation is the one under consideration, along with its unique associated body of interpretational aids.

Sometimes a jurisprudence of state constitutional positivism is justified on the ground that, because state constitutions are so easily and frequently amended, it is often possible actually to discern "the framers' true intent"4 in a way that is sometimes impossible to accomplish when interpreting the U.S. Constitution due to its age. Thus, the argument goes, whatever its potential flaws as a tool of federal constitutional interpretation, a jurisprudence of original intent can be effective when applied to state constitutions. Others have argued that the tendency of state constitutions to regulate a wide variety of governmental activities in great detail makes many provisions of state constitutions unsuitable for any kind of analysis other than a purely textual one. ${ }^{5}$ More generally, though, constitutional positivism is typically defended on the ground that it is the only sound methodology for interpreting any constitution, whether state or national. This is the view taken by adherents of what has come to be known as the "primacy" approach to state constitutional interpretation. ${ }^{6}$ It is the view that I wish primarily to dispute.

A frequently-expressed frustration in the field of state constitutional law is that state courts often fail to follow the prescribed methodology of constitutional positivism: they ignore subtle (and sometimes not-so-subtle) cues contained in the state constitutional text; they fail to inquire into the views of the state constitution's framers; and they undertake no meaningful investigation into the history of their state or the development of its constitution. ${ }^{7}$ Instead, state courts frequently look to federal constitutional law for guidance: they examine the text of the U.S. Constitution, the writings of Madison, Hamilton, and other key framers of the federal Constitution; and rely heavily on decisions of the U.S. Supreme Court. ${ }^{8}$ Sometimes state courts seem to assume that the meaning of state constitutional provisions is given more by national sources of constitutional meaning than by any distinctive attributes of the state constitution itself,

\footnotetext{
${ }^{4}$ Hon. Vito J. Titone, State Constitutional Interpretation: The Search for an Anchor in a Rough Sea, 61 ST. JoHN's L. REV. 431, 460 (1987). To the same effect is Tarr, supra note 1, at 196.

${ }^{5}$ William F. Swindler, State Constitutions for the Twentieth Century, 50 NEB. L. REv. 577, 593 (1971). For similar views, see Tarr, supra note 1, at 195; James Gray Pope, An Approach to State Constitutional Interpretation, 24 RUTGERS L.J. 985, 1004-05 (1993).

${ }^{6}$ Some of the leading works in this school of thought include Hans Linde, First Things First: Rediscovering the States' Bills of Rights, 9 U. BALT. L. REv. 379 (1980); Hans Linde, E Pluribus -- Constitutional Theory and State Courts, 18 GA. L. REV. 165 (1984); Robert F. Williams, In the Supreme Court's Shadow: Legitimacy of Rejection of Supreme Court Reasoning and Result, 35 S.C. L. REV. 353 (1984); Robert F. Williams, Methodology Problems in Enforcing State Constitutional Rights, 3 GA. ST. U. L. REV. 143 (1987).

${ }^{7}$ For examples of state courts ignoring textual differences, see, e.g., Reid v. Gholson, 327 S.E.2d 107 (Va. 1985) (ignoring considerable textual differences between the religion clauses of the First Amendment and Va. Const. art. I, ' 16); State v. Ceci, 255 A.2d 700 (Del. Sup. Ct. 1969) (ignoring the fact that Del. Const. art. I, § 5 protects only the freedom of the press, and treating it as though it also contained a speech clause); Ramada Inns, Inc. v. Dow Jones \& Co., Inc., 1988 Del. Super. LEXIS 29; 15 Media L. Rep. 1586 (Del. Sup. Ct. 1988) (same). On the failure of state courts to inquire into the intentions of the framers or make other historical inquiry, see James A. Gardner, The Failed Discourse of State Constitutionalism, 90 MicH. L. REV. 761, 793-94 (1992). On the inept analysis by state courts of constitutional history, see Jack L. Landau, A Judge's Perspective on the Use and Misuse of History in State Constitutional Interpretation, 38 VALPARAISO U. L. REV. 451 (2004).

${ }^{8}$ Linde, First Things First, supra note 6, at 387-92; Linde, E Pluribus, supra note 6, at 186-88; Todd F. Simon, Independent but Inadequate: State Constitutions and Protection of Freedom of Expression, 33 KAN. L. REv. 305, 308 (1985).
} 
and they thus incorporate federal constitutional doctrine wholesale into state constitutional jurisprudence. Although this practice has been the subject of frequent and intense criticism, ${ }^{9} \mathrm{I}$ shall argue that it is in fact often a logical response to the situation in which judicial interpreters of state constitutions find themselves, in large part because orthodox constitutional positivism simply is not a viable interpretational methodology for subnational constitutions in a federal system.

The application of constitutional positivism to state constitutions has been criticized before, most often by invoking interpretational models that challenge the conceptual foundations of constitutional positivism itself. Critiques by Paul Kahn and Lawrence Friedman, for example, proceed from a dialogic model of constitutional meaning, ${ }^{10}$ and Robert Schapiro has offered a theory of state constitution making that abandons reliance on an intentional correspondence between a self-conscious polity and its governing constitutional document. ${ }^{11}$ While these critiques are useful and potent, the one I offer here is different in that it preserves the basic assumptions and conceptual structure of constitutional positivism, which is after all a very good theory -- in our time, the preeminent theory -- on which to sustain and legitimize indirect, republican democracy. What I wish to show, however, is that the premises of constitutional positivism cannot, except with substantial modification, be coherently applied to the constitutions of the American states.

Part II of this Chapter sets out the political theory of constitutional positivism and its attendant ideology of interpretation. Part III turns to the federal structure of American government, and argues that the status of subnational units in a true federal system violates the conditions necessary to justify the interpretational methods of constitutional positivism. Part IV draws out some of the implications of this disjunction for state constitutional interpretation, Part $\mathrm{V}$ examines some potential complications of my analysis, and Part VI concludes.

\section{Constitutional Positivism}

The basic theory of constitutional positivism is Lockean, and it tells a familiar story about the significance of constitutions and the source of their legitimacy as fundamental law. According to this story, autonomous individuals, self-ruling in the state of nature as a matter of natural law, agree voluntarily for their own mutual security and advantage to band together into a civil society. ${ }^{12}$ In so doing, each member of the society gives up his or her natural right of self-

\footnotetext{
${ }^{9}$ See especially Williams, In the Supreme Court's Shadow, supra note 6, at 389-97; Tarr, supra note 1, at 180-82; Robert F. Williams, In the Glare of the Supreme Court: Continuing Methodology and Legitimacy Problems in Independent State Constitutional Rights Adjudication, 72 Notre DAME L. ReV. 1015 (1997).

${ }^{10}$ Paul W. Kahn, Interpretation and Authority in State Constitutionalism, 106 HARV. L. REv. 1147 (1993); Lawrence Friedman, The Constitutional Value of Dialogue and the New Judicial Federalism, 28 HASTINGS Const. L. Q. 93 (2000). Similar points are made in Ann Althouse, Federalism, Untamed, 47 VAND. L. REv. 1207, 1219-20 (1994); Rachel A. Van Cleave, State Constitutional Interpretation and Methodology, 28 N.M. L. REv. 199, 203-05 (1998). For an earlier, related example, see Robert M. Cover \& T. Alexander Aleinikoff, Dialectical Federalism: Habeas Corpus and the Court, 86 YALE L.J. 1035 (1977).

${ }^{11}$ Robert A. Schapiro, Identity and Interpretation in State Constitutional Law, 84 VA. L. REv. 389 (1998).

${ }^{12}$ John Locke, The Second Treatise Of Government (Thomas P. Peardon, ed., Bobbs-Merrill 1952) ( $1^{\text {st }}$ ed. $1690), \S \S 4,87,89$ at $4,48-50$.
} 
rule to the collective group. Having thus entered into a self-governing society, society's members -- now known as "the people" -- generally find it advantageous to create a government to handle the chores associated with collective self-rule. The government, on this view, is thus no more than a servant or agent of the people, and can exercise only the powers that have been delegated by the people, and then only in a way that the people have authorized. ${ }^{13}$ A government that has been duly appointed by the people and acts within the bounds of its delegated powers is "legitimate" -- it has the right, and not merely the power, to make laws binding on society. A constitution, on this view, is simply a positive statement of the instructions of the principal (the people) to its agents (the government), and that is why government officials must strictly obey and implement the will of the people as it is expressed in their constitution. ${ }^{14}$ This is, of course, the familiar story of the American founding, one that is told and retold in the canonical texts of American law. ${ }^{15}$ It provides, in Eugene Rostow's words, "the prevailing political theory of modern times and the only modern rival for the doctrine that power proceeds from the barrel of a gun," 16 and it furnishes the theoretical foundations of constitutionalism itself. To a very great extent, we are all constitutional positivists.

The political theory of constitutional positivism also provides an accompanying theory of legitimate constitutional interpretation. Because a constitution contains the positive and binding instructions of the people, judges, who are themselves only specialized public servants, must construe the constitution consistent with the will of those who made it. Consequently, according to constitutional positivism, judicial review consists in the main of an attempt to discern and faithfully to enforce the will of those who made and adopted the constitution. ${ }^{17}$

Nevertheless, just because constitutional positivism provides the central narrative account of the U.S. Constitution does not necessarily make it the best account of state constitutions. Constitutional positivism makes a number of critical assumptions about the nature of the polity and its relation to its constitution, three of which are relevant here. Under constitutional positivism, the polity that creates the constitution must have three characteristics: it must be (1) unique, (2) determinate, and (3) self-constructed.

The uniqueness requirement assures a one-to-one correspondence between a polity and its constitution. Under the constraints of Lockean political theory, there can be only one people, one government (or perhaps one collection of governments), and consequently one set of instructions from principal to agent. By definition, on this view, it is not possible for one people to give binding instructions to another people's government, nor would a government be acting legitimately were it to obey instructions issued by some people other than the one that created it and to which it owes obedience. Thus, we would not expect the Supreme Court of Canada to obey commands contained in the U.S. Constitution, nor could Americans legitimately harbor any

\footnotetext{
${ }^{13}$ Id., $\S \S 134-142$, at $75-82$.

${ }^{14}$ Originalism, for example, is only one very strong account of what is necessary for judges to assure their obedience to the popular will. See Gardner, supra note 3, at 21-22.

${ }^{15}$ Declaration of Independence (U.S. 1776); U.S. Const preamble; McCulloch v. Maryland, 17 U.S. 316 (1819).

${ }^{16}$ Eugene R. Rostow, The Rightful Limits of Freedom in a Liberal Democratic State: Of Civil Disobedience, in Is LAW DEAD? (Eugene R. Rostow, ed. 1971).

${ }^{17}$ AleXAnder Hamilton, The Federalist, No. 78 (Clinton Rossiter, ed. 1961), at 466-69; Marbury v. Madison, 5 U.S. 137, 174-76 (1803).
} 
expectation that Canadians will obey the U.S. Constitution, either in lieu of or in addition to their own.

The closely related determinacy criterion requires that it be clear who comprises the polity that is entitled to issue binding commands to any particular governmental agent. In a regime of constitutional positivism there must be one and only one principal -- but who is it? For constitutional positivism to function effectively, a government must be able to identify with some precision who is and who is not a member of the unique polity entitled to issue it instructions, knowledge that permits it to know exactly where -- that is to say, in what constitution -- its unique set of binding instructions may be found. ${ }^{18}$ It is not enough for a court to know that it is, say, the agent of the people of Italy, or of Argentina, if there is any significant question about who comprises the members of those polities. The most familiar kinds of indeterminacy problems appear when nations begin to break down; for example, officials of the Yugoslavian government in the mid-1990s might have known that they owed obedience to the Yugoslavian people and their constitution, but have been thoroughly confused as to who comprised that people, and just which constitution contained the instructions that Yugoslavian officials were required to obey. Similar problems have arisen in some of the Commonwealth countries as they have gradually disengaged themselves from British oversight. ${ }^{119}$

Finally, according to constitutional positivism, a polity must be self-constructed, meaning that its members, and they alone, must be the ones who decide to form an independent civil society and to create constitutional rules for their collective self-governance. A basic premise of Lockean theory is that a group forms its own civil society to take itself out of the larger world, to create a self-contained enclave of complete self-sovereignty. For such a transaction to be meaningful, the decision of the members to constitute themselves a polity must be voluntary and rational -- done, that is, on their own volition and not, say, at the instigation of some other group. Operation of this requirement may occasionally be seen in the international community's refusal to recognize new nations when it suspects that they have been formed less than fully voluntarily,

\footnotetext{
${ }^{18}$ The kind of uncertainty I refer to must be distinguished from the normal kinds of uncertainty that, in Lockean theory, nearly always accompany any attempt to identify with precision the membership of a given polity. For example, in- and out-migration, the status of resident aliens, and problems arising from the intergenerational transmission of consent may all complicate questions of political membership. But these kinds of problems are endemic in contractarian political theory and are not generally thought to pose insurmountable problems.

${ }^{19}$ A particularly acute example of this problem arose upon Southern Rhodesia's unilateral declaration of independence from Britain in 1965. Courts sitting in the former colony owed their existence to a 1961 colonial constitution conferred by Britain, yet were permitted to continue to sit pursuant to Rhodesia's 1965 revolutionary constitution. This presented difficult problems of constitutional pedigree for the judges. See F. M. Brookfield, The Courts, Kelsen, and the Rhodesian Revolution, 19 U. TORONTO L. J. 326 (1969). The same problem, though in a very different context, has arisen in Canada, for which there is no clearly identifiable event marking the moment when it ceased to be a British colony and became an independent nation. Instead, it has acquired independence from Britain in a slow, evolutionary process. Moreover, Canada has never formally adopted a constitution; the Canadian Constitution consists of a mix of statutes, common law, and customary practices, many of which, including the constitution's centerpiece, the 1867 British North America Act, date to the era of British rule. Canadian constitutional history is well recounted in Peter H. Russell's excellent book, CONSTITUTIONAL ODYSSEY: CAN Canadians Be A Sovereign People? (1992). According to Russell, as recently as the 1960s, when the Canadian Constitution was still formally the product of British statutory law, "Canadians had not yet been able to agree on the locus of constitutional sovereignty in the nation they were endeavouring to build." Id. at 57.
} 
for example under pressure from outside forces. The former South African Bantustans fit this description, ${ }^{20}$ and the same principle helps explain why American Indian reservations are not understood to be truly independent nations.

The conditions of uniqueness, determinacy, and self-construction, then, are necessary to justify interpreting a constitution using the methods of constitutional positivism. These are exactly the conditions, however, that American state polities fail to satisfy, and which indeed cannot be satisfied by any subnational unit in a system of true federalism, as in the American case.

\section{Federalism and Subnational Units: Whose Constitution Is It?}

\section{A. Subnational Autonomy}

In any multilevel system of governance -- in any system, that is, other than a completely centralized and unitary one -- the relationship between the national and subnational units of government may range across a potentially broad spectrum of subnational autonomy. At one end of the spectrum, a subnational unit may possess complete or very nearly complete autonomy and consequent independence from the national government. This is the arrangement that might prevail in a treaty league or a confederacy, such as existed in the United States under the Articles of Confederation. At the other end of the spectrum, subnational units may occupy a status of complete or very nearly complete subordination to the national government, and thus enjoy virtually no meaningful autonomy. This would be the situation in a highly centralized government with a system of strict hierarchical decentralization, as for example with the départements of France. ${ }^{21}$

Federalism, at least when it is genuine rather than merely nominal, ${ }^{22}$ sits uneasily in the middle of this spectrum. In a truly federal system, subnational units are partly dependent and partly independent; partly autonomous and partly subordinate. A subnational unit's autonomy may be restricted territorially or by area of competence, or both; residuary powers may be allocated to the national government or to the subnational units. ${ }^{23}$ Whatever the precise arrangement, in all such cases the people of the subnational unit have the authority to govern themselves as they see fit in some instances, but not in all instances. They are autonomous sovereigns for some purposes but not for others, or with respect to some subjects but not others. A subnational unit in a federal system is thus simultaneously an independent, autonomously selfgoverning entity, guided solely by the independently formulated wishes of its own polity, and a hierarchically subordinate dependency of the national government, required to adhere to

\footnotetext{
${ }^{20}$ John Dugard, South Africa's “Independent” Homelands: An Exercise in Denationalization, 10 J. INT'L L. \& Policy 11, 11-16 (1980); BRian Bunting, THe Rise Of THE SOUTH AFRica Reich 309-16 (1964).

${ }^{21}$ Norman Dorsen, ET AL., COMPARATIVE CONSTITUTIONALiSM 387 (2003).

22 The charge is sometimes made that American federalism has degenerated from a system of genuine federalism to a merely nominal one that is much closer to a centralized national system. E.g., ROBERT F. NAGEL, THE IMPLOSION OF AMERICAN FEDERALISM (2001).

${ }^{23}$ For overviews of subnational autonomy in federal systems around the world, see CHESTER JAMES ANTIEAU, States' Rights under Federal Constitutions (1984); Ronald L. Watts, Foreword: States, Provinces, Lander, and Cantons: International Variety among Subnational Constitutions, 31 RUTGERS L.J. 945 (2000).
} 
decisions made by a national polity that is essentially external to it, even when its own polity would, if given the chance, choose some other course.

\section{B. Joint Ownership of State Constitutions}

The indeterminate status of subnational units in a federal system calls into question the extent to which their constitutions can be viewed in the positive sense. A useful heuristic for framing this inquiry is to consider the question: Whose constitution is it? If constitutional positivism is to be available as a theoretical framework for an interpretational methodology, the answer must be that a state's constitution "belongs" -- uniquely, determinately, and by virtue of a process of independent and voluntary self-construction -- to the people of that state, and to them alone. Yet it is clear that the constitutions of the American states cannot satisfy this definition. If we ask to whom does the constitution of an American state belong, we must conclude that the best answer, at least from the point of view of constitutional positivism, is that a state constitution belongs jointly to the polities of both the state and the nation.

This property of joint ownership shows up most obviously in the very basic fact that the U.S. Constitution establishes the outer boundaries of the constitutional space that any state polity may lawfully occupy by imposing direct, binding limitations on the content of state constitutions. $^{24}$ Thus, no matter how earnestly a state polity may desire them, a state constitution may not validly contain provisions violating equal protection or due process, or limiting the privileges and immunities of American citizens from other states, or impeding interstate commerce, or establishing a state currency, or erecting an aristocratic form of government, and so on. ${ }^{25}$ These restrictions place significant limitations on the state polity's agency, limitations that are severely in tension with the premises of constitutional positivism, especially the requirement of political self-construction. Moreover, the partial subordinacy of states in a federal system means that instructions to the state government come from two different constitutions, state and national, and by implication from two different polities, also state and national. State governments thus serve two masters simultaneously, violating constitutional positivism's uniqueness requirement.

Another difficulty arises from the fact that, under the U.S. Constitution, state polities are legally disabled from unilaterally defining and constructing themselves. Article IV of the U.S. Constitution provides specifically that new states may be admitted into the union only with the permission of Congress, and prohibits the creation of a new state within the territory of any other state without the permission of the states concerned as well as of Congress. ${ }^{26}$ Furthermore, it is the Constitution of the United States, and not of any state, that establishes the system of federalism in the first place, and it is to that decision of the national polity, and not to the

\footnotetext{
${ }^{24}$ For a comparative overview, see Robert F. Williams \& G. Alan Tarr, Subnational Constitutional Space: A View from the States, Provinces, Regions, Länder, and Cantons, in G. Alan TARR, Robert F. WILLIAMS, AND Josef MARKo, EDS., FEDERALISM, SUBNATIONAL CONSTITUTIONS, AND MinORITY Rights (2004).

${ }^{25}$ U.S. Const. amend. XIV, $\S 1$ (equal protection and due process), art. IV, § 2 (privileges and immunities), art. I, §

8 , cl. 3 (commerce), art. I, $\S 10$, cl. 1 (currency, titles of nobility).

${ }^{26}$ U.S. Const. art. IV, $\S 3$.
} 
decision of any existing or putative state polities, that states owe their existence. ${ }^{27}$ The presence of these constraints means that the decision to form a state, to say nothing of the decision to include it in the federal union, is a decision made not by the state polity in question, but jointly by the state and national polities acting together. These considerations further undermine both the uniqueness and self-construction requirements of constitutional positivism.

The problems with applying constitutional positivism to the states, however, go deeper still. Although it is the reigning theory of American constitutionalism, constitutional positivism is somewhat limited by certain Enlightenment-era assumptions about human nature on which it is based. ${ }^{28}$ According to more recent political theories that take a more realistic view of how constitutions function in the political and social world, constitutions are more than sets of exogenously-generated instructions issued by rationally self-constructed collections of individuals; they also form a crucial part of the social matrix that shapes the individuals and societies that live according to constitutionally decreed rules. ${ }^{29}$ In other words, the arrow of causality points in both directions: constitutions do not merely reflect political choices made by polities, but also in significant ways help to frame those choices by establishing a social context in which political preferences are conceived and formulated. In this way, it is true not only that a people creates a constitution, but also that a constitution helps create a people. ${ }^{30}$

On this view, the fact that an American state polity must live not only under its own state constitution but also under the national Constitution has significant consequences for its identity. If a constitution not only reflects but also reciprocally constitutes the identity of the polity that lives under it, then the polity of an American state is constituted simultaneously by both the state and national constitutions. Since every state polity is partly constituted by the U.S. Constitution, every state polity necessarily shares to some extent the national polity's values, commitments, and history -- in short, its identity.

To make matters even more confusing, this sharing of identity occurs not only on the level of collective political identity, but on the individual level as well. In the American political

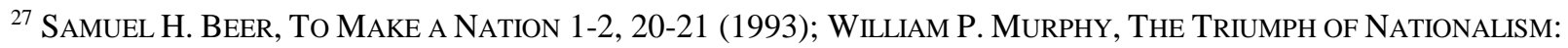
StATE SOVEREIGNTY, THE Founding FATHERS, AND THE MAKING OF THE CONSTITUTION (1967).

${ }^{28}$ Constitutional positivism derives from classic liberalism, which is often said to rely on an unrealistically atomistic theory of individuals. See, e.g., Charles Taylor, Atomism, in AlKIS Kontos, ED., PowERS, PossESSIONS AND FreEdoms: EsSAYS IN HONOR OF C.B. MACPHERSON 39-61 (1979); MichAEL J. SANDEL, LiBERALISM AND THE LIMITS OF JUSTICE 9 (1982) (in liberal theory, the individual is conceived to be "prior to and independent of experience" and thus "prior to its ends").

${ }^{29}$ This view is often associated with communitarianism. Leading works include ALASDAIR MACINTYRE, AFTER VIRTUE (2d ed. 1984); Sandel, supra note 28; BENJAMIN BARBER, STRONG DEMOCRACY: PARTICIPATORY POLITICS FOR A NEW Age (1984). It is also associated with the law and literature movement. See JAMES B. WHITE, HeraCles' Bow (1985); JAMES B. White, Justice AS TRANSLATION (1990); Richard Delgado, Storytelling for Oppositionists and Others: A Plea for Narrative, 87 MICH. L. REV. 2411 (1989). In state constitutional law specifically, see Gardner, Failed Discourse, supra note 7, at 815-22; Schapiro, supra note 11, at 393 ("The constitution does not reflect a preexisting community of value, but rather creates its own community.").

${ }^{30}$ See BenEdict ANDERSON, IMAGINED COMMUNITIES: REFLECTIONS ON THE ORIGIN AND SPREAD OF NATIONALISM (rev. ed. 1991) (arguing that nations do not necessarily reflect coherent preexisting communities, but rather result from collective leaps of imagination, often stimulated by artifacts in the shared environment).
} 
system, every citizen of a state is also automatically a citizen of the nation, ${ }^{31}$ and consequently all Americans are members simultaneously of both their state and national polities. This dual social membership necessarily contributes to a uniting, or at least a substantial blurring, of the two identities, and suggests strongly that they are mutually constraining through principles of individual personal integrity. As the philosopher Alasdair MacIntyre has explained, human life is embedded in narratives: we explain ourselves to ourselves and to others, and from such accounts acquire our identity. ${ }^{32}$ But because personal identity is based on an intelligible narrative account of oneself, identity can never be wholly unconstrained; one's identity cannot be just anything one wishes it to be, but rather is inevitably constrained by the bounds of narrative plausibility: "personal identity is just that identity presupposed by the unity of the character which the unity of a narrative requires. Without such unity there would not be subjects of whom stories could be told." ${ }^{33}$ Because of this narrative drive toward unity in personal identity, individual membership in distinct communities becomes difficult to sustain the more the communities are understood to differ in important respects. One way to resolve this tension is to choose between communities, ${ }^{34}$ but where choice is not an option the only alternative is to attempt to hold things together by intellectually minimizing the differences between the communities to which one belongs. For Americans, this very likely means that there are important social limitations on how different our state and national communities, and thus our state and national identities, can ever be.

If a constitution reflects the identity of the polity that creates it, the identity of a state polity in a federal system is yoked in a significant way to the national identity, and thus cannot differ greatly from it. But this seepage of identity from state to nation and from nation to state is in considerable tension with the premise of constitutional positivism holding that the authors of a constitution have a political identity that is determinate. In the American system of federalism, it is difficult to tell where national identity ends and state identity begins. Again, then, the more realistic position is to conceive of state constitutions as the joint product of the state and national polities.

To put the point another way, it may be possible to preserve constitutional positivism as an interpretational methodology for state constitutions, but only by radically reconceiving the nature of the polity that creates them. Orthodox constitutional positivism requires that we conceive of a state polity as a unique, voluntary, distinct, and self-defined civil association, but that is clearly far from accurate. If constitutional positivism is to be retained, it must be adapted to recognize that the polity that makes a state constitution is fuzzy and ill-defined; its membership at any given moment includes elements of both the state and national citizenries. Moreover, the locus of the polity to which the state constitution is attributable is not necessarily settled, as constitutional positivism requires, but may wander between the two conventionally

\footnotetext{
${ }^{31}$ U.S. Const. amend. XIV, § 1.

${ }^{32}$ MacIntyre, supra note 29, ch. 15.

${ }^{33}$ Id. at 218. Charles Taylor has made a similar argument. See Charles TAYlor: SourCES Of THE Self: The MAKING OF THE MODERN IDENTITY 27, 47-52 (1989).

${ }^{34}$ This was the option chosen by Southerners upon seceding from the union, and it was typically justified on the ground that the differences between Southerners and the rest of the nation had become too great. For an account, see James A. Gardner, Southern Character, Confederate Nationalism, and the Interpretation of State Constitutions: A Case Study in Constitutional Argument, 76 TEX. L. REV. 1219, 1252-55 (1998).
} 
defined poles of state and national citizenries depending upon the particular issue or constitutional provision in question. In a federal system, then, a state polity simply is not a fixed, unique, and determinate entity, a problem that greatly complicates the application of the methods of constitutional positivism to the interpretation of state constitutions.

\section{Implications for Interpretation}

The foregoing analysis permits us to draw some rough conclusions concerning the circumstances in which constitutional positivism is capable of furnishing a valid justificatory theory of constitutional interpretation. First, constitutional positivism clearly makes sense for national constitutions; they furnish the paradigm case, and undoubtedly the foundational premises of constitutional positivism make their closest approach to reality when a national polity frames and lives under a national constitution. To invoke the heuristic of ownership mentioned earlier, a national constitution thus "belongs to" the national polity in the strongest possible way.

Second, in the case of subnational constitutions, constitutional positivism makes the most sense at the extreme ends of the spectrum of subnational autonomy referred to earlier. In a treaty league or confederacy, where subnational units enjoy nearly complete autonomy, constitutional positivism again furnishes a good description of the relation between polity and constitution at the subnational level. Here, because the subnational unit has a degree of autonomy that approaches closely the autonomy enjoyed by independent nations, the subnational constitution is created by, and thus belongs to, the subnational polity, which is therefore the source of the complete or nearly complete stock of constitutional norms. In such a governmental structure, interpreters of the subnational constitution may confidently apply the interpretive prescriptions of constitutional positivism.

Conversely, at the other end of the autonomy spectrum, subnational units are merely decentralized hierarchical subordinates of the national government; they lack any independent agency and are bound to implement authority that is merely delegated from the central government, much like an administrative agency. Here, too, constitutional positivism furnishes a useful conceptual framework, for it tells us that subnational constitutions in such a system must be interpreted solely in light of national rather than subnational norms and interpretational aids. In a highly centralized system of governance, subnational governments are essentially servants of the national government, so their constitutions will be fully determined by norms established at the national level. The subnational constitution, in other words, belongs to the national polity.

In a federal system, however, neither subnational nor national sources of meaning are likely by themselves to tell the whole story. Because the state polity has considerable independent agency in a federal system, subnational sources of meaning will clearly be highly relevant to interpretations of the state constitution. At the same time, however, national norms in such a system are part of the constituting matrix of the state polity and, by implication, its constitution; the state polity, as we have seen, cannot be neatly separated from its national counterpart. Consequently, ownership of a state constitution in a federal system is shared to 
some degree ${ }^{35}$ and constitutional positivism is thus at its least effective in describing the constitutional document and in prescribing a suitable methodology of constitutional interpretation.

If constitutional positivism does not adequately capture the situation of the American state constitution, how, then, ought such documents to be interpreted? This is not the place to attempt a comprehensive answer, ${ }^{36}$ but it seems clear, if constitutional positivism is to be preserved as a guide to interpretation, that it must be adapted to take account of the fact that the state constitution is not solely a product of the state polity, but is rather the outcome of more comprehensive processes in which both the state and national polities participate. At a minimum, then, to interpret a state constitution in these circumstances inevitably will require at least some resort to national norms and sources of constitutional meaning. Interpreters of state constitutions thus will need to search for the meaning of the document not only in state sources of meaning, such as the text and history of the state constitution, the intentions of its framers, and the precedential decisions of state courts, but also in corresponding national norms, history, experience, and precedent.

To look solely at state sources of meaning, ${ }^{37}$ as advocates of strict constitutional positivism demand, is to exclude from the analysis potentially useful or even critical information upon which to base a meaningful interpretation of the state constitution. To be sure, national sources of constitutional meaning may not always significantly illuminate the meaning of the state constitution; doubtless some provisions of state constitutions owe their contemporary meaning to influences and processes that are so overwhelmingly local that an examination of national history, precedent or values will yield little information of relevance. ${ }^{38}$ At other times, however, national sources of constitutional meaning may, entirely on their own, provide a complete and satisfying account of the meaning of a provision of the state constitution, and in other cases the construction of a satisfactory account may require resort to some combination of state and national sources of meaning. At bottom, then, a sound approach to state constitutional interpretation requires a willingness to examine both kinds of sources, state and national. ${ }^{39}$

\footnotetext{
${ }^{35}$ The degree of sharing may differ from system to system, see, e.g., Martha A. Field, The Differing Federalisms of Canada and the United States, 55 LAW \& CONTEMP. PROB. 107 (1992), or even from state to state within a single federal system. See G. Alan Tarr, Creating Federalism in Russia, 40 S. TEX. L. Rev. 689 (1999) (describing asymmetrical federalism in Russia).

${ }^{36}$ I attempt a more complete, though still far from comprehensive, answer in, JAMES A. GARDNER, INTERPRETING

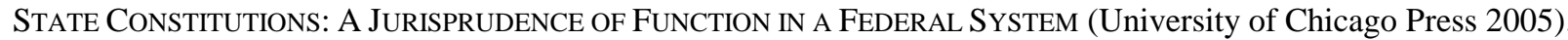

${ }^{37}$ Paul Kahn refers to this body of information as "unique state sources." Kahn, supra note 10, at 1147-50.

${ }^{38}$ See Pope, supra note 4, at 991-94 (identifying several instances in which state constitution making has been informed by deliberate and distinctive local choices).

${ }^{39}$ A similar argument might be made about the interpretation of state statutes, although it would be significantly more attenuated, mainly because legislative positivism rests on a legitimating theory that is further removed from the identity-blurring problems I have been discussing. According to the prevailing theory of legislative positivism, statutes are the product of a duly appointed legislature possessing the delegated authority to make laws binding within the relevant political jurisdiction. In consequence, the touchstone for all statutory interpretation is the intent of the legislature. Legislatures, however, are emphatically not self-created, nor do they ordinarily suffer from structural ambiguities of uniqueness or determinacy. It is conceivable that such problems could arise, but one would expect them to result from some kind of political crisis rather than from a permanent structural feature of the legislative system, as is the case with subnational constitutions in a federal system. Nevertheless, one might still say
} 
This is, of course, precisely what state courts already do. One of the most common phenomena in state constitutional law is so-called "lockstep" interpretation, in which state courts construe provisions of state constitutions to have precisely the same meaning as similar provisions of the U.S. Constitution. ${ }^{40}$ In conducting a lockstep analysis, or even in conducting more sophisticated "adoptionist" analyses, in which federal constitutional law is first consulted and then voluntarily incorporated into the body of state constitutional law, ${ }^{41}$ state courts frequently examine the text, founding history, and federal judicial interpretations of the U.S. Constitution. In so doing, state courts apparently recognize that the meaning of the state constitution can be illuminated by looking to national sources of constitutional meaning. For this they have been routinely criticized. My argument here suggests, however, that this criticism is not always well founded.

\section{Complications}

Having laid out my basic position, I now turn briefly to some potential complications of my analysis. First, I want to clarify the difference between the approach I have been defending and two commonplace practices of American courts. The first of these practices occurs when courts interpreting one constitution consult the decisions of other jurisdictions as an aid to interpretation. The second practice involves the interpretation of what I call constitutional "wormholes": provisions in constitutions that deliberately incorporate concepts or values developed by, and borrowed from, other polities. In each of these situations, courts deliberately examine the constitutional law of a jurisdiction other than the one whose constitution they are construing, yet neither practice has ever been thought to be inconsistent with the premises of constitutional positivism. I conclude by discussing the possibility of including in a state constitution positive meta-instructions to the judiciary to ignore "outside" sources of constitutional meaning.

\section{A. Consulting Decisions from Other Jurisdictions}

American courts have a long tradition of consulting related rulings from other jurisdictions when analyzing issues arising under the law of their own jurisdictions. While the process of interjurisdictional consultation is probably most familiar in common law fields, ${ }^{422}$

\footnotetext{
that state legislatures partake of ambiguities like those that characterize state polities because the ambiguities that exist in a state legislature's constitutional environment are necessarily ramified within the legislature itself, so that the intentions of state legislators must occasionally be construed by reference to national constitutional or statutory norms. While there is something to this argument, I am inclined to think that about the furthest one might plausibly go in this direction would be to say that national norms are relevant to the interpretation of state statutes only insofar as the interpretation of a state statute requires examination of principles embodied in the state constitution. In any other situation, the intentions of a state legislature are probably better viewed for all practical purposes as a sufficiently strong intervening cause to overwhelm the much more attenuated connections to national norms.

${ }^{40}$ For an overview, see Robert F. Williams, State Courts Adopting Federal Constitutional Doctrine: Case-by-Case Adoptionism or Prospective Lockstepping?, 46 WM. \& MARY L. REV. 1499 (2005)..

${ }^{41}$ Id. at $1505-20$.

${ }^{42}$ E.g., Bradley Canon and L. Baum, Patterns of Adoption of Tort Law Innovations: An Application of Diffusion Theory to Judicial Doctrines, 75 AM. POL. SCI. REV. 975 (1981)
} 
where courts are free from the kinds of decisional constraints imposed by the obligation to obey positive law, it also occurs in constitutional law despite the fact that the answers to constitutional questions are in principle to be found exclusively within the four corners of the relevant constitution. ${ }^{43}$ So, for example, in taking up a question arising under the search and seizure provisions of the U.S. Constitution, the U.S. Supreme Court might consider how state courts have construed similar provisions of state constitutions, ${ }^{44}$ and a state court facing a similar question might consult the constitutional search and seizure jurisprudence of other state courts or of the U.S. Supreme Court. ${ }^{45}$

This kind of interjurisdictional consultation, however, has not typically been thought to be inconsistent with the principles of constitutional positivism. ${ }^{46}$ Indeed, some of the leading exponents of state constitutional positivism have maintained that there is no basis for objecting to state judicial consultation of federal constitutional rulings, provided those rulings are given only the weight to which their persuasive value entitles them. ${ }^{47}$ But if constitutional positivism permits this kind of routine interjurisdictional consultation, then doesn't constitutional positivism provide a suitable method for interpreting state constitutions after all?

The answer is no: subnational constitutional interpretation in a federal system contemplates a closer relationship between state and national constitutional law than is captured in the kind of interjurisdictional consultation approved by proponents of state constitutional positivism. When state courts merely "consult" similar decisions from other jurisdictions, they are conventionally understood to be doing something optional, and the consulting court typically considers itself equally free to attend to or to ignore the consulted opinions; consultation, in other words, is not premised on a belief that judicial rulings from other jurisdictions are in any sense

\footnotetext{
${ }^{43}$ I include here the set of unique interpretational aids conventionally associated with every constitution, such as the founding history and framers' intentions, for example. Although it has been persuasively argued that constitutional decision making has much more in common with common law decision making than is generally recognized, David A. Strauss, Common Law Constitutional Interpretation, 62 U. CHI. L. REv. 131 (1995), that is a complication I wish for present purposes to set aside.

${ }^{44}$ See, e.g., Mapp v. Ohio, 367 U.S. 643 (1961).

${ }^{45}$ Examples of both kinds of consultation appear in, e.g., Commonwealth v. Edmunds, 586 A.2d 887 (Pa. 1991) (consulting both state and federal rulings in determining whether to read a "good faith" exception into the state constitution's protection against unreasonable searches and seizures); State v. Oakes, 598 A.2d 119 (Vt. 1991) (same). In its stronger forms, of course, consultation shades into adoption, prompting complaints about lockstep analysis. See Williams, State Courts Adopting Federal Constitutional Doctrine, supra note 40.

${ }^{46}$ A recent exception is Justice Scalia's vociferous objection to the U.S. Supreme Court's consultation of decisions from foreign jurisdictions in the course of construing the federal Constitution. See Lawrence v. Texas, 539 U.S. 558, 586 (2003) (Scalia, J., dissenting); Atkins v. Virginia, 536 U.S. 304, 347-48 (2002) (Scalia, J., dissenting).

${ }^{47}$ See, e.g., Tarr, supra note 1, at 182 ("if a state court decides to conform its interpretation of a state provision to the Supreme Court's interpretation of an analogous federal provision, this decision has to be based on the persuasiveness of the Court's argument"); Williams, In the Supreme Court's Shadow, supra note 6, at 403 (noting that U.S. Supreme Court opinions are entitled to weight as "persuasive authority in state constitutional interpretation," but observing that they deserve less weight than "decisions of sister state jurisdictions"); Linde, First Things First, supra note 6, at 392 (quoting with approval statement by Hawaii Supreme Court in State v. Kaluna, 520 P.2d 51, 58 n.6 (1974) to the effect that U.S. Supreme Court decisions are "to be afforded respectful consideration"); Linde, E Pluribus, supra note 6, at 179 ("Of course we pay attention and respect to Supreme Court opinions on issues common to the two constitutions"); William J. Brennan, Jr., State Constitutions and the Protection of Individual Rights, 90 HARV. L. REV. 489, 503 (1977) (state judges should follow federal court decisions "only if they are found to be logically persuasive and well-reasoned").
} 
binding within the consulting jurisdiction. Rather, courts seem to consult rulings from other jurisdictions more to educate themselves than to inquire into any authoritative constraints on how they themselves may rule. In consulting other decisions, then, judges seek only to gain the benefit of relevant human experience for the purpose of sharpening their own decision making; the consulted ruling carries no more intrinsic weight than would a work of history, say, or a law review article.

Once again, the point may be clarified by considering the relationship between state and national constitutional law as ranging across a spectrum. At one end of the spectrum, state constitutional law is completely controlled by the content of national constitutional law, and state judges are thus required not only to consult but to follow national law because it fully determines the meaning of state constitutional provisions. This is the kind of unreflective lockstep analysis that commentators have properly criticized. The criticism is warranted because, in a genuinely federal system, the state polity has some degree of independent agency in the formulation of its constitutional rules of self-governance and courts cannot assume, except upon the strongest evidence, that the state polity has chosen entirely to forgo any exercise of that agency.

At the other end of the spectrum, state and national constitutional law are completely independent, such that national constitutional law has no formal relationship whatsoever to state constitutional law; they are jurisprudential strangers. This is where interjurisdictional consultation comes into the picture. Here, state courts may educate themselves by consulting similar decisions from other jurisdictions, but they are not required to do so, and when they do consult such decisions they may do as they please with whatever information they might happen to acquire. This is the position taken by proponents of the primacy approach. This position, however, simply makes a mistake that is the mirror image of unreflective lockstepping, for it assumes, wrongly as I have argued above, that a state constitution in a federal system is the product solely of the state polity. On this view, the national polity has no agency in the construction of the state constitution, and the national polity's constitution, history, identity, values, and judicial precedents can therefore be treated as though they were entirely external to the state constitution. Consequently, if consulting federal decisions does happen to prove useful, that utility results more from good luck and happenstance than from any systematic structural relation between the two documents.

My argument here is for a middle position between these two extremes. In a genuinely federal system, state constitutional law is partly independent from national constitutional law, but also partly dependent upon it. State courts cannot assume the identity of state and national constitutional law because states are not administrative subdivisions of the national government, but neither may they assume the kind of complete independence from national constitutional law that constitutional positivism requires, because states in federal systems are not fully independent sovereigns. As a result, state courts must do more than merely "consult" federal constitutional law in the hope that such a chance encounter might yield useful ideas or arguments. Instead, state courts must approach the state constitution with the understanding that national constitutional law may, in many though perhaps not in all cases, provide information necessary to comprehend its meaning. Resort to national sources of constitutional meaning is, then, an 
integral part of the process of elucidating the meaning of the state constitution, not an optional consultation to be undertaken by judges who happen to have the time and inclination.

\section{B. Wormholes}

Another instance in which constitutional positivism permits judges to look to the constitutional law of other polities when construing their own constitution is where the constitution in question contains provisions that have been deliberately copied from other constitutions. ${ }^{48}$ In these situations, it is often said that the borrowed provision must be given the same meaning as it had under the constitution from which it was borrowed at the time of the borrowing. ${ }^{49}$ The borrowed provision thus contains a constitutional anomaly, a "wormhole" to another constitutional dimension: stick your hand into this constitutional provision and it emerges somewhere far away, in the constitutional universe of an entirely different jurisdiction. For example, the framers of "Article I, ' 6 of the Delaware Constitution, a provision protecting individuals from unreasonable searches and seizures, self-consciously copied it in 1792 from the Pennsylvania Constitution of $1791 .^{50}$ As a result, courts of Delaware to this day interpret the provision by looking to decisions of the Pennsylvania Supreme Court construing the provision of the Pennsylvania Constitution from which the Delaware provision was borrowed. ${ }^{51}$

On the surface, this approach to borrowed provisions seems to violate the uniqueness requirement of constitutional positivism because it requires a court construing the borrowed provision to consult the will of a polity other than the one to which it owes constitutional obedience. In fact, however, the conceptual integrity of constitutional positivism is preserved in these situations by assigning to the founding polity itself responsibility for requiring the interpreting court to look for the meaning of a constitutional provision in the constitutional law of another jurisdiction. Consequently, when a court of state A interprets a provision of A's constitution by examining the constitutional text, history, framers' intentions, and precedent of state B, it does so because the polity of state A has so instructed it. Because the court is merely

\footnotetext{
${ }^{48}$ For a useful overview, see Tarr, supra note 1 , at 50-56.

${ }^{49}$ E.g., Tarr, supra note 1, at 207 ("one chooses not only the text but the consequences of that textual formulation, as indicated by the judicial decisions interpreting the text"). Sometimes the much stronger (and untenable) claim is made that the borrowed provision must be construed in tandem with the source provision even when the meaning of the source provision evolves as a result of judicial rulings made in the source jurisdiction subsequent to the borrowing. This position, however, results in a kind of constitutional lockstep that is inconsistent even with the premises of constitutional positivism. See John Devlin, State Constitutional Autonomy Rights in an Age of Federal Retrenchment: Some Thoughts on the Interpretation of State Rights Derived from Federal Sources, 3 EMERGING ISSUES ST. CONST. L. 195 (1990); Tarr, supra note 1, at 207.

${ }^{50}$ Jones v. State, 745 A.2d 856, 860 n.12, 865-66 (Del. 1999).

${ }^{51}$ Id. at 866 . The Pennsylvania Constitution is also a source for some provisions of the Kentucky Constitution, and decisions of the Pennsylvania courts construing the source provisions carry special weight in Kentucky.

Commonwealth v. Wasson, 842 S.W.2d 487, 498 (Ky. 1992). Even federal constitutional jurisprudence occasionally invokes a wormhole jurisprudence. For example, the Supreme Court has interpreted the Seventh Amendment's guarantee of a right to jury trial to incorporate by reference the state of the common law right to a jury trial as it stood at the time of the adoption of the Bill of Rights, in 1791. Baltimore \& Carolina Line, Inc. v. Redman, 295 U.S. 654, 657 (1935). The Seventh Amendment is thus a wormhole that directs interpreters to the common law of the eighteenth century.
} 
obeying the binding instructions of the polity to which it owes obedience, it is not violating, but is on the contrary complying with, the tenets of constitutional positivism.

The problem that I have addressed in this Chapter, however, is not simply a wormhole problem writ large. My argument is not that a state court should look to national sources of constitutional meaning because the state polity has instructed its courts to do so, or should be understood tacitly to have permitted the use of national sources. My point is rather that a state court attempting to adhere to the protocol of constitutional positivism will in some cases find it impossible to arrive at a complete and satisfying understanding of certain provisions of the state constitution without looking to national sources of constitutional meaning. Reference to national sources is thus in many circumstances required, regardless of whether the state polity has authorized it.

\section{Meta-instructions to Ignore "Outside" Sources}

The final complication I wish to address is the possibility that a state polity might affirmatively forbid state courts to consult national sources of constitutional meaning. That is, the state polity might include in the state constitution meta-instructions to the judiciary concerning how to interpret the document. What would happen if such an instruction required state courts to interpret the state constitution by relying solely on state sources of meaning, such as the state constitutional text and history and the intentions of the state constitution's framers, and to ignore national sources of meaning $?^{52}$ Would this be sufficient to negate my analysis?

I think not. In fact, I think such an instruction would in many cases prove impossible to obey because of the ambiguous identity of the state polity, and would do nothing more than shift the locus of ambiguity from one place to another. I argued earlier that the unsuitability of constitutional positivism for the interpretation of state constitutions is demonstrated by asking the question "whose constitution is it?" A meta-instruction to ignore non-state sources of constitutional meaning attempts to answer this question by fiat, in essence by claiming: "this constitution belongs to us -- the polity of this state."

The general futility of attempting to solve interpretational ambiguities by definitional fiat ought to be apparent. ${ }^{53}$ In any event, here the relevant ambiguity would simply be referred to the

\footnotetext{
52 This is not a wholly speculative possibility. Provisions in the constitutions of Florida and California, for example, require that certain rights guarantees in the state constitution be construed solely in accordance with federal constitutional norms. Cal. Const. art. I, § 7; Fla. Const. art. 1, 12 . Conversely, a different provision of the California Constitution and a provision of the Rhode Island Constitution permit, but do not require, courts to construe state constitutional rights provisions according to norms other than those informing the U.S. Constitution. Cal. Const. art. I, § 24; R.I. Const. art. I, § 24.

${ }^{53}$ The critical problem is that it is impossible for a principal, whether an individual, a polity or a legislature, to control by fiat the way in which its agents construe its instructions. This is because interpretation always takes place in a context, and it is impossible for any actor within that context to exercise complete control over the context in which it issues its instructions, much less to control the way in which that context is understood (interpreted) by others acting within or upon it. William N. Eskridge, Jr., Spinning Legislative Supremacy, 78 GEO. L.J. 319 (1989). But there is no need to press this position here, since the more modest argument given in the text is sufficient to rebut the contention.
} 
next level of inquiry. Instead of asking "whose constitution is it?" the court would have to confront different but equally intractable questions: Who is the "you" of which the state polity consists? Which sources of constitutional meaning are "yours" and which are "theirs"?

For example, would it be permissible for a state court operating under such an instruction to consult the Declaration of Independence? The Declaration is generally thought to be a "national" source of constitutional meaning, but it so deeply influenced the thinking of generations of drafters and ratifiers of state constitutions that to exclude resort to it might seriously compromise a state court's ability to make sense of certain provisions of the state constitution, or certain episodes in the state's history, or certain important statements by the framers of the state constitution. Thus, the challenge that federalism poses to subnational constitutional positivism cannot be made simply to disappear, but must be confronted at some point or another in the process of interpreting state constitutions.

\section{Conclusion}

Constitutional positivism is a powerful and widely accepted political theory of governmental and constitutional legitimacy, and there are consequently good and tempting reasons to rely upon it for the purpose of legitimizing judicial interpretation of constitutions. It is important, however, not to confuse the power of a theory with its applicability; political theories derive their power in part from their plausibility in the settings in which they are applied. In particular, it is tempting to think that because constitutional positivism supplies a plausible account of interpretational legitimacy for judicial review of the U.S. Constitution, it is capable of doing the same for judicial review of American state constitutions. But this appropriation rests on a faulty premise: it assumes, wrongly, that constitutional positivism applies just as straightforwardly to subnational constitutions as it does to the paradigm case of national constitutions. Although constitutional positivism may, without modification, provide useful guidance for construing subnational constitutions in certain kinds of multilevel systems of governance, in a genuinely federal system it does not. This is because subnational polities in a federal system lack several characteristics that constitutional positivism deems them to possess, making it an unsuitable method, at least in its conventional form, for application to the constitutions of the American states.

Constitutional positivism can, however, be retrieved as a useful methodology for interpreting state constitutions, but only by relaxing some of its methodological prescriptions. In particular, we must abandon the idea that the meaning of a state constitutional provision is determined solely by reference to sources of meaning associated with that constitution. Instead, interpreters of state constitutions must recognize that elucidation of the meaning of provisions of state constitutions may from time to time require them to consult not only state sources of constitutional meaning, but also corresponding national sources. That is, the meaning of the state constitution may be determined not only by the state constitutional text, state constitutional history, intentions of the framers of the state constitution, and prior state constitutional precedent, but also by the history, values, experience and precedent associated with the U.S. Constitution. 
Despite a steady stream of academic criticism, state judges have often looked to federal constitutional law to guide their interpretation of the state constitution. My analysis here suggests that academic commentary would be better directed not to criticizing state judges for resorting to national sources of constitutional meaning, but rather to educating them about how best and in what circumstances to do so. 